\title{
Studia
}

\author{
Timothy Blauvelt \\ Ilia State University, Gruzja
}

\section{Zmiana statusu i etniczna mobilizacja podczas wydarzeń marca 1956 roku w Gruzji}

\author{
Status Shift and Ethnic Mobilisation in the March 1956 Events in Georgia
}

\begin{abstract}
The large-scale demonstrations that took place in Georgia in early March 1956 following Khrushchev's criticism of Stalin at the 20th Party Congress were the first significant expressions of public protest and civil disobedience in the Soviet Union for decades, and they also bore a clearly nationalistic character. Based primarily on materials from the Georgian KGB and Party archives and interviews with former Party officials and participants of the events, this article examines potential interpretations of these events derived from elite incorporation and ethnic mobilisation theories.
\end{abstract}

Keywords - Status Shift, Ethnic Mobilisation, March 1956 Events in Georgia

Wydarzenia rozgrywające się na początku marca 1956 roku w Tbilisi, stolicy Gruzińskiej Socjalistycznej Republiki Radzieckiej, potoczyły się w sposób, który jeszcze niedawno uznano by za niemożliwy. 4 marca, w przededniu trzeciej rocznicy śmierci Stalina, ludzie zaczęli gromadzić się przed jego pomnikiem w pobliżu nadrzecznego bulwaru, by wziąć udział w uroczystościach upamiętniających - podobnych jak w ubiegłych latach. Jednak z upływem dni zgromadzenie stawało się coraz potężniejsze, wyglądało jak dwie duże, nieprzerwanie się odbywające demonstracje - jedna pod pomnikiem Stalina, a druga w centrum miasta, na placu Lenina (dziś placu Wolności) - z udziałem dziesiątków tysięcy ludzi. Rozeszły się plotki o „tajnym liście” Moskwy do kierownictwa republiki krytykującym Stalina i oskarżającym go o potworne zbrodnie.

Zrazu w mowach, pieśniach i wierszach demonstranci oddawali cześć Stalinowi, stopniowo jednak pojawiały się tony bardziej nacjonalistyczne. Podobne demonstracje rozpoczęły się w innych miastach Gruzji, m.in. Gori, Kutaisi, Batumi, Suchumi. Radykalizowały się żądania mówców i działania tłumu. Ulicami tam i z powrotem jeździły samochody, a znajdujący się w nich ludzie machali flagami i trąbili. Grupy studentów zaczęły rekwirować duże ciężarówki. Kiedy studenci i uczniowie przyłączyli się do demonstracji, zamknięto szkoły i uniwersytety, przerwało też pracę wiele fabryk i biur.

9 marca napięcie sięgnęło zenitu. Pierwszy sekretarz partii komunistycznej Wasilij Mżawanadze przemówił w Tbilisi do zgromadzonych, godząc się na pewne ustępstwa, m.in. opublikowanie artykułów wspomnieniowych i zorganizowanie oficjalnych uroczystości w gmachach publicznych, ale nie uspokoiło to demonstrantów. Centrala

\footnotetext{
1 Artykuł był po raz pierwszy drukowany w: „Europe-Asia Studies” 2009, nr 4 (61). Redakcja „Wolności i Solidarności” dziękuje autorowi i wydawcy - Taylor \& Francis Ltd, www.tandfonline.com, za zgodę na publikację polskiej wersji.
} 
wysłała do miasta oddziały wojska do ochrony budynków rządowych. Kiedy około godziny 22.30 tłum ruszył na siedzibę urzędu telekomunikacji przy alei Rustawelego, żołnierze otworzyli ogień z broni automatycznej. Padło wielu zabitych $i$ rannych, a tłum ogarnęła panika. Nazajutrz, 10 marca wczesnym rankiem czołgi i oddziały piechoty rozproszyły siłą drugą demonstrację - pod pomnikiem Stalina na nadbrzeżnym bulwarze 2 .

Wydarzenia marca 1956 roku uważa się coraz częściej za punkt zwrotny we współczesnej historii Gruzji, choć do dziś niektóre pytania pozostają bez odpowiedzi, np. o liczbę zabitych i rannych, stopień zorganizowania demonstracji, rolę kierownictwa partii w Tbilisi. Ale chyba najważniejsze pytania dotyczą rzeczywistych celów wielotysięcznej rzeszy demonstrantów. Czy powodowała nimi prosta miłość do Stalina? Czy był to raczej wyraz autentycznego oburzenia Gruzinów i ich narodowych aspiracji?

W artykule tym motywacje i cele przyświecające wydarzeniom marca 1956 roku chcemy przeanalizować na podstawie materiałów archiwalnych gruzińskiego KGB i Komitetu Centralnego, a także wywiadów z byłymi funkcjonariuszami partii i uczestnikami demonstracji. Chcemy też przetestować kilka możliwych interpretacji opartych na teoriach średniego zasięgu - ,włączania elit” i „etnicznej mobilizacji” - wyjaśniających, jak i dlaczego doszło do tamtych wydarzeń, przekonać się, jak dalece pasują one do dostępnej wiedzy. Interpretacje oparte na teorii włączania elit sugeruja, że czynnikiem motywacyjnym mogła być dla demonstrantów postrzegana przez nich „Zmiana” statusu republiki. Z kolei interpretacje korzystające z teorii etnicznej mobilizacji uwzględniają możliwość podsycania demonstracji przez gruzińskie kierownictwo, które było zainteresowane celami politycznymi, chciało zwłaszcza zapobiec zmianie statusu lub złagodzić jej skutków.

Nie ulega wațpliwości, że na początku roku 1956 w całym Związku Radzieckim Stalin znaczył wiele dla ludzi. Przez ćwierć wieku społeczeństwo poddawano ideologicznej indoktrynacji, karmiąc je nieustanną propagandą o Wielkim Wodzu, jego przymiotach i dokonaniach. „Tajny referat” Chruszczowa na XX Zjeździe KPZR zadał potężny cios sposobowi myślenia i światopoglądowi mieszkańców całego ZSRR. Jednak w przypadku Gruzji chodziło chyba o coś więcej, nie tylko o to, że Gruzini kochali Stalina bardziej niż pozostali radzieccy obywatele. Stalin był jednym z nich, więc potępienie go przez centralne kierownictwo w Moskwie mogło w części gruzińskiego społeczeństwa wywołać żywiołowy odruch narodowego oburzenia. W przypadku jeszcze liczniejszego grona, zwłaszcza części młodych elit, oburzenie to zapewne nie było wyłącznie żywiołowe - status Stalina rzutował bezpośrednio na status Gruzji i Gruzinów.

Zgodnie z kompromisem wypracowanym w trakcie formowania się Związku Radzieckiego poszczególne grupy etniczne zorganizowane zostały w ramach jednostek terytorialnych różniących się wielkością, statusem i przywilejami przysługującymi „tytułowym” narodowościom. Jak pisał Rogers Brubaker ${ }^{3}$, państwo radzieckie „instytucjonalizowało byt licznych narodów i grup etnicznych jako konstytutywnych elementów składowych państwa i jego obywateli” zarówno poprzez organizację terytorialną, jak i osobiste zaklasyfikowanie. Radzieckie potraktowanie kwestii narodowościowej zaowocowało powstaniem całej hierarchii jednostek terytorialnych, które Terry Martin ${ }^{4}$ nazwał „przerośniętą piramidą radzieckich narodowości, złożoną się z tysięcy różnej wielkości terytoriów etnicznych". Pod koniec epoki stalinowskiej najważniejszym wyznacznikiem statusu i przywilejów tych terytoriów były ich rozmiar i typ. Na szczycie hierarchii znajdowały się republiki związkowe (i ich tytularne elity), niżej zaś mniej uprzywilejowane republiki autonomiczne, obwody autonomiczne, kraje i obwody. Z uwagi na ogromne zróżnicowanie jednostek narodowo-terytorialnych pod względem wielkości, zasobów, stopnia rozwoju i poziomu edukacji jednostki te różnicowały się dalej, tworząc strukturę zwieńczoną federalną hierarchią republik związkowych, w której niekwestionowany prym wiodła republika rosyjska, a inne walczyły o dalsze pozycje.

\footnotetext{
2 Por. obszerne omówienie wydarzeń marca 1956 r. w: S. Nozadze, 1956 tragikuli 9 marti, Tbilisi 1992; W.A. Kozłow, Massonyje biesporiadki w SSSR pri Chruszczonie i Breżniewie - 1953-1980 gody, Novosibirsk 1999.

${ }^{3}$ R. Brubaker, Nationhood and the National Question in the Soviet Union and Post-Soviet Eurasia: An Institutionalist Account, „Theory and Society” 1994, nr 1 (23), s. 49.

${ }^{4}$ T. Martin, An Affirmative Action Empire: The Soviet Union as the Highest Form of Imperialism [w:] A State of Nations: Empire and Nation Making in the Age of Lenin and Stalin, red. R.G. Suny, T. Martin, New York 2001, s. 73.
} 
Jak podkreślał Martin, praktyka radzieckiego federalizmu nie oznaczała delegowania realnej władzy politycznoekonomicznej. Stalinowska mantra o „narodowej formie i socjalistycznej treści” oznaczała raczej to, że aspekty narodowościowe uchodzące za niesprzeczne ze scentralizowaną państwowością - jak nazwy geograficzne, kultura, język, a także nominacje i awanse w obrębie lokalnych elit - były w gestii jednostek narodowo-terytorialnych, podczas gdy faktyczna władza należała do centrali. „Odpolitycznieniu narodowej tożsamości służyło ostentacyjne demonstrowanie poszanowania tożsamości nierosyjskich” jako „formy symboliczne” obejmujące terytorium, kulturę, język i kadry5. Dlatego owe „formalne” aspekty stawały się nie tylko narodowymi i etnicznymi symbolami tym, co Martin nazywa „etnicznością symboliczna” - lecz także wyznacznikiem statusu w ramach radzieckiej hierarchii narodów konkurujących o zasoby i przywileje. I na odwrót - także aspekty symboliczne, takie jak etniczne pochodzenie elit, stawały się upolitycznionym wskaźnikiem etnicznego statusu. Jak zauważył Yuri Slezkine ${ }^{6}$, ,narodowa forma zdawała się zmieniać w treść”, a „nacjonalizm zdawał się nie mieć innej treści niż kult formy”.

Ze względu na opisaną instytucjonalna, narodowo-terytorialną strukturę państwa radzieckiego i mimo że sam Stalin był nie tyle gruzińskim nacjonalista, ile wielkoruskim szowinista, a Gruzini cierpieli tak samo, jeśli nie bardziej, jak inne republiki wskutek masowych czystek pod jego rządami, fakt, że Stalin był Gruzinem, miał określone skutki dla statusu Gruzinów i gruzińskiej republiki związkowej w ramach radzieckiej hierarchii narodów.

David Laitin ${ }^{7}$, opierając się po części na wcześniejszym schemacie Johna Armstronga ${ }^{8}$, sformułował „teorię makro” relacji wewnątrzgrupowych w wieloetnicznych imperiach, którą nazwał „,modelem ekspansji państwa przez włączanie elit”. To, jak kategoryzowana jest dana narodowość w ramach systemu, zależy głównie od możliwości, jakie metropolia i reszta imperium oferuja jej elitom. W wariancie nazwanym przez Laitina „awansem faworytów” elity mniejszości etnicznych zyskują niemal takie same przywileje i możliwości awansu jak elity etnicznej większości, natomiast w wariancie zwanym przez niego „kolonialnym” miejscowe elity nie mogą awansować na szczeblu centralnym, a tylko w ograniczonym stopniu na poziomie regionalnym.

W epoce stalinowskiej nikt w Gruzji i całym Związku Radzieckim nie miał watpliwości co do specjalnego statusu Gruzji i Gruzinów. Świadczyło o tym nie tylko to, że Gruzinem był Wielki Przywódca, ale i wysoki status takich członków kierownictwa jak „Sergo” Ordżonikidze czy Lawrientij Beria, terytorialny rozrost Gruzińskiej Socjalistycznej Republiki Radzieckiej za rządów Stalina, to, że w ostatnich latach Stalin często odpoczywał w czarnomorskich kurortach, co dawało gruzińskim przywódcom ogromna przewagę w postaci bezpośredniego dostępu, wyraźna tolerancja reżimu dla korupcji i politycznego nepotyzmu w Gruzji (pomijając parę prób rozprawienia się z problemem) budząca resentymenty w całym ZSRR, wreszcie, co najważniejsze, awansowanie Gruzinów na najwyższe stanowiska w związkowej nomenklaturze, a zwłaszcza służbach bezpieczeństwa (w tym grupy protegowanych Berii) ${ }^{9}$. Można więc zasadnie argumentować, że w czasach stalinowskich Gruzini spełniali kryteria pozwalające zaliczyć ich do Laitinowskiej kategorii „awansujących faworytów”"

Dlatego dla wielu Gruzinów, zwłaszcza młodych, ambitnych członków elity, skrytykowanie przez Chruszczowa stalinowskiego „kultu jednostki” i oficjalne potępienie Stalina ledwie dwa i pół roku po potępieniu Berii i usunięciu jego protegowanych z najwyższych stanowisk miało zapewne ogromną symboliczną wymowę jako jednoznaczna zapowiedź końca specjalnego statusu Gruzji i jej degradacji z „,awansującego faworyta” do jakiejś innej, niższej kategorii. Gruzińskie elity różnych szczebli dostrzegły bezpośrednie zagrożenie swych przywilejów, odbierające im raz na zawsze szanse awansu poza własną republiką, w Moskwie i w całym Związku Radzieckim, którymi się dotąd

\footnotetext{
${ }^{5}$ Ibidem, s. 75.

${ }^{6}$ Y. Slezkine, The USSR as a Communal Apartment, or How a Socialist State Promoted Ethnic Particularism [w:] Becoming National: A Reader, red. G. Ely, R.G. Suny, New York 1996, s. 237.

7 D. Laitin, Identity in Formation: The Russian Speaking Populations in the Near Abroad, Ithaca 1998.

${ }^{8}$ J.A. Armstrong, The Ethnic Scene in the Soviet Union: The View of the Dictatorship [w:] The Soviet Nationality Reader: The Disintegration in Context, red. R. Denber, Boulder 1992.

${ }^{9} 23$ maja 1956 r. na posiedzeniu Prezydium KPZR w Moskwie po wydarzeniach marcowych, na które wezwano gruzińskie kierownictwo, Chruszczow zwracał uwagę na te przywileje, stwierdzając, że „za czasów Berii Gruzja znalazła się poza kontrolą Komitetu Centralnego”; „to była niewłaściwa polityka, Gruzji dano więcej”, dlatego „zaczął rozkwitać nacjonalizm” (Rosyjskie Państwowe Archiwum Historii Najnowszej - Rossijskij Gosudarstwiennyj Archiw Nowiejszej Istorii, f. 2, o. 12, d. 1004, k. 46-47.

${ }^{10}$ Jak pisał John Armstrong (The Ethnic Scene..., s. 244): „Niezwykle silne u Gruzinów poczucie narodowej tożsamości wynikało zapewne bardziej ze szczególnej roli, jaką odgrywali w czasach Stalina, dzieląc z Rosjanami pozycję dominującej w ZSRR grupy etnicznej”.
} 
cieszyły. Potępienie Stalina oznaczało odebranie Gruzji uprzywilejowanej pozycji w radzieckiej hierarchii narodowości, znaczącą zmianę statusu z republiki „awansowanych faworytów” na coś gorszego, może wariant „kolonialny".

Trudno rzecz jasna o zgeneralizowaną ocenę motywów dziesiątków tysięcy ludzi ponad pół wieku po analizowanych wydarzeniach. Nie ulega wątpliwości, że dla niektórych ludzi wystarczającym powodem do manifestacji było zwyczajne oburzenie pogłoskami o tym, że obrażono Stalina; nie wszyscy zgadzali się z coraz bardziej nacjonalistycznymi żądaniami radykalizujących się demonstrantów. Większością powodowała zapewne mieszanka emocji i motywacji nie zawsze w pełni świadomych i wyartykułowanych. W ostatecznym rozrachunku skala uczuć nacjonalistycznych dających się faktycznie zauważyć podczas demonstracji marca 1956 roku była mniej ważna niż nacjonalistyczna mitologia, jaką w kolejnych dziesięcioleciach nasiąkły w oczach Gruzinów tamte wydarzenia wskutek siłowej kontrakcji i dużej liczby ofiar cywilnych ${ }^{11}$.

Jednak przynajmniej część uczestników tamtych wydarzeń musiała w jakimś stopniu rozumieć, że destalinizacja oznacza zakwestionowanie dotychczasowej pozycji Gruzinów. Jak pisał Kozłow ${ }^{12}$, „w marcu 1956 r. mieszkańcy Tbilisi nie protestowali jedynie przeciwko kolejnej niezrozumiałej politycznej decyzji najwyższego przywództwa, ale przeciwko narodowej zniewadze z rąk »Moskwy«”. Wiele lat później jeden z nich pisał13: „Sytuacja, która zyskała zadowalające rozwiązanie w 1955 r., skomplikowała się - narastała krytyka i oficjalne potępienie Stalina (na XX zjeździe partii). W oczach Rosjan oficjalne stanowisko było ostatecznym, niezmiennym wyrokiem historii przeciwko Gruzinom, który w ich rozumieniu nie miał żadnego usprawiedliwienia, jakim byłoby »lepsze« życie lub życie jako takie, i wynikał z tego tylko, że Stalin był ich [Gruzinów] rodakiem. Ale w oczach Gruzinów był to wymierzony w nich bezpardonowy atak".

Władze centralne w Moskwie dostrzegały nacjonalistyczne elementy wydarzeń w Tbilisi - świadczy o tym język uchwały prezydium KC KPZR z 10 lipca 1956 roku „O błędach i nieprawidłowościach w pracy Komitetu Centralnego Komunistycznej Partii Gruzji”, wedle której gruziński komitet „,nie doceniał tego, że zło stalinowskiego kultu jednostki zakorzeniło się głęboko w świadomości gruzińskiego społeczeństwa, przybierając ogromne rozmiary i nacjonalistyczny wydźwięk”"14.

Bardziej umiarkowane postulaty demonstrantów odzwierciedlały zranioną dumę narodową, uwzględniając symbolikę statusu narodowego - powinny odbywać się oficjalne obchody na cześć Stalina, jego imię winno nadal figurować w nazwie konstytucji ZSRR, artykuły o nim winny ukazywać się w gazetach i czasopismach, kręcone i pokazywane winny być filmy o nim, delegacja centralnego kierownictwa powinna przyjechać do Tbilisi i wytłumaczyć nową linię partii, a „tajny list” z instrukcjami dotyczącymi potępienia Stalina winien być zwrócony do Moskwy ${ }^{15}$.

W bardziej radykalnych wystapieniach, m.in. w przemówieniu z 9 marca, przypisywanym w raportach milicyjnych Rubenowi Kipianiemu, pojawiły się żądania ustąpienia kierownictwa partii (przede wszystkim Chruszczowa i Bułganina), a także mianowania na wysokie stanowiska w centralnym kierownictwie partyjnym takich przedstawicieli elity i etnicznych Gruzinów jak I sekretarz gruzińskiej partii Wasilij Mżawanadze, były I sekretarz Akaki

11 S. Jones, Georgia: Nationalism from Under the Rubble [w:] Nationalism after Independence: the Post-Soviet States, red. L. Barrington, Ann Arbor 2006, s. 255. W miesiącach po wydarzeniach marcowych w raportach wewnętrznych KGB informowało niezmiennie o 21 zabitych i 54 rannych (Archiwum Gruzińskiego Ministerstwa Spraw Wewnętrznych - Sakartwlos sachmtsipo usziszoebis saministros arkivi, SSUSA), f. 6, d. 159, k. 19-26). Co interesujące, w raporcie dla Komitetu Centralnego z 22 marca szef KGB Iwan Sierow znacząco pomniejszył liczbę ofiar, piszac o czterech zabitych 9 marca (SSUSA, f. 6, d. 159, k. 29). Teczka ta, zatytułowana „1956 clis 9 martis mowlenebtan dapawszirebuli masalebis prebuli", zawiera kopie korespondencji gruzińskiego Politbiura z Komitetem Centralnym i KGB w Moskwie na temat wydarzeń marcowych. Została przekazana do Wydziału Archiwalnego gruzińskiego MSW na jego wniosek przez Wydział Archiwalny FSB w Moskwie we wrześniu 2000 r. Więcej o zasobach archiwów gruzińskiego KGB i Komitetu Centralnego na temat marca 1956 r. w: T.K. Blauvelt, Patronage and Betrayal in the Post-Stalin Succession: The Case of Kruglov and Serov, „Communist and Post-Communist Studies” 2008, nr 1 (41).

12 W.A. Kozłow, Massowyje biesporiadki..., s. 156.

${ }^{13}$ N. Notadze, Sischliani paraskemi [w:] 9 marti, 1956. Kadrszi da kadrgaret, red. G. Wepchwadze, Tbilisi 2001, s. 100.

14 Partyjne Archiwum Komitetu Centralnego Komunistycznej Partii Gruzji - Prezydenckie Archiwum Gruzji (Partarchiw CK KPG), f. 14, o. 31, d. 208, Informacje komitetów obwodowych KPG o wynikach dyskusji na temat uchwały KC KPZR z 10 VII 1956 r. „O błędach i nieprawidłowościach w pracy Komitetu Centralnego Komunistycznej Partii Gruzji”, k. 69.

15 SSUSA, f. 6, d. 159, Telegram szefa gruzińskiego KGB Inauriego do szefa KGB Sierowa, 17 III 1956, k. 5. 
Mgeladze i syn Stalina Wasilij. Żądano też rehabilitacji Berii i jego ludzi oraz przywrócenia na stanowiska kierownicze tych, którzy przeżyli (m.in. byłego I sekretarza z Azerbejdżanu Bagirowa) ${ }^{16}$.

Makwala Okroperidze, młoda kobieta aresztowana później przez KGB jako współorganizatorka demonstracji w Gori, wołała podobno do tłumu: „Chruszczow, Bułganin i Mołotow chcą oszukać gruziński naród, ale Gruzini nie powinni się ich bać - powinni sformułować swoje żądania i uzyskać słuszne zadośćuczynienie”17. Według raportu Iwana Sierowa dla Komitetu Centralnego z 22 marca 1956 roku „ten przejaw burżuazyjnego nacjonalizmu nie spotkał się ze sprzeciwem zgromadzonych, mało tego, wielu powitało go aplauzem i okrzykami aprobaty"18.

Także na zamkniętych zebraniach partyjnych organizowanych w całej republice w tygodniach i miesiącach po wydarzeniach marcowych powracał żal z powodu zranionej dumy narodowej i utraconego statusu. Na zebraniach tych w marcu i kwietniu członkom gruzińskiej partii po raz pierwszy udostępniono tajny referat Chruszczowa o kulcie jednostki. Po jego odczytaniu na zebraniu organizacji partyjnych regionu Tbilisi 3 kwietnia 1956 roku z sali padły anonimowe pytania. Członkowie partii chcieli wiedzieć, czy śmiertelne strzały do tłumu 9 marca były „wskazówka, czy ostrzeżeniem” (skașytie, ukazanie eto by to ili prieduprieżdienie?), ,jakim interesom czy celom służą dochodzenia związane ze Stalinem?”, „komu służy ten list towarzysza Chruszczowa?”19.

Prowokatorzy i chuligani zwiedli młodzież - głosiła standardowa interpretacja przedstawiana na zamkniętych zebraniach partyjnych. Jej typowym przykładem było wystapienie przewodniczącego uczelnianej organizacji partyjnej gruzińskiej politechniki: „praca polityczno-wychowawcza wśród studentów była niedostateczna, czego dowodem są haniebne wydarzenia 9 marca, podczas których podejrzani prowokatorzy wykorzystali ponure nastroje naszej młodzieży”20. Niektórzy mówcy podkreślali autentyzm patriotycznych uczuć uczestników wydarzeń. Przemawiając na zamkniętym zebraniu Związku Pisarzy, zwołanym nazajutrz po strzałach, 10 marca, pisarz Konstantin Gamsachurdia powiedział: „Autentyczne uczucia młodzieży zostały brutalnie wykorzystane przez prowokatorów, którzy dążąc do swych oszukańczych celów, doprowadzili do konfrontacji, wskutek czego padły ofiary"21. Podczas innych zebrań mówcy zaczynali od wyrażenia aprobaty dla linii partii, ale potem stawiali te same postulaty, co demonstranci22.

Podczas demonstracji i w późniejszych miesiącach gniew i frustracja Gruzinów kierowały się głównie przeciwko etnicznym Rosjanom i Ormianom. Odczucia te mogły niewątpliwie ulec wzmocnieniu wskutek wydarzeń marcowych, ale wiele dowodów wskazuje, że dawały o sobie znać także podczas demonstracji. W wielu raportach mowa o atakowaniu przez demonstrantów pojedynczych rosyjskich żołnierzy i cywilów ${ }^{23}$. Telegram KGB z 5 marca informował Moskwę o ulotkach pojawiających się w Kutaisi, a potem Tbilisi „obrażających rosyjski naród i wzywających Gruzinów, by dali wyraz swemu oburzeniu”24. Szczególną wściekłość budził Anastas Mikojan - wzywano do odsunięcia go, bezczeszczono publicznie jego portrety ${ }^{25}$.

\footnotetext{
16 SSUSA, f. 6, d. 406-56, Akta sprawy kryminalnej przeciwko Rubenowi Kipianiemu. We wniosku z dochodzenia prokuratura wojskowa wspomina, że tłum wznosił okrzyki „Niech żyje nasz drogi Beria!” (SSUSA, f. 6, d. 416-56, k. 7). W telegramie do szefa KGB w Moskwie Iwana Sierowa z 26 marca mowa jest o tłumie, który zaatakował i bił mjr. Kulewa, krzycząc: „Dlaczego ty, Azer, nie wyniesiesz się do Baku, bronić Bagirowa? Dlaczego nie pozwalasz nam bronić Berii?” (SSUSA, f. 6, d. 159, k. 16).

17 SSUSA, f. 6, d. 375-56, k. 110.

18 SSUSA, f. 6, d. 159 , s. 32.

19 Partarchiw CK KPG, f. 14, o. 31, d. 212, k. 55-56.

${ }^{20}$ Ibidem, k. 63.

${ }^{21}$ Partarchiw CK KPG, f. 14, o. 31, d. 197, k. 14.

${ }^{22} \mathrm{Na}$ przykład instruktorka w tkalni w Tbilisi, towarzyszka T. Kalidze, kończąc swoje wystapienie na zamkniętym zebraniu organizacji partyjnej w kwietniu 1956 r. stwierdziła, że można było zapobiec wydarzeniom 9 marca. „Wystarczyło, żeby ludzie nie dowiedzieli się o tym, co zrobił tow. Chruszczow po XX zjeździe partii. Nie jest przyjęte, żeby bić kogoś po jego śmierci, on jednak podeptał nieśmiertelne imię Stalina. Oskarżam delegatów na XX zjazd partii wybranych przez gruzińską organizacje partyjna, którzy nie odrzucili referatu tow. Chruszczowa. Wiemy o istnieniu pewnego tajnego listu. Domagam się natychmiastowego odesłania go z powrotem!”. To samo według doniesień mówili robotnicy Kadżaja i Czandari (Partarchiw CK KPG, f. 14, o. 31, d. 197, k. 15-16).

${ }^{2}$ SSUSA, f. 6, d. 416-56, k. 3.8 marca tłum zaatakował brutalnie grupę oficerów w alei Rustawelego, krzycząc: „To rosyjscy oficerowie, załatwmy ich!" (ibidem, k. 16).

${ }^{24}$ SSUSA, f. 6, d. 159, k. 4.

25 Ibidem. Te same meldunki donoszą, że protestujący tłum nazywał radzieckich żołnierzy „faszystami” i „sługusami Mikojana”.
} 
W ściśle tajnym raporcie Zakaukaskiego Okręgu Wojskowego KGB dla I sekretarza gruzińskiej partii Mżawanadzego na temat doniesień informatorów cytujących wypowiedzi studentów w Batumi w miesiącach po wydarzeniach marcowych widoczna jest wyraźna wrogość wobec Rosjan (choć, powtórzmy, mogła ona być tyleż przyczyna, ile skutkiem owych wydarzeń). Na przykład studenci Wydziału Kultury Fizycznej Uniwersytetu Batumi demonstracyjnie odmówili dyskutowania na ćwiczeniach z ekonomii politycznej o kulcie jednostki, a studentka rosyjskiego pochodzenia, która próbowała odpowiedzieć na pytania prowadzącego zajęcia, została „wulgarnie zakrzyczana”. Student, Gruzin, powiedział: „Nie martw się, pokażemy wam, Rosjanom. Jak zacznie się wojna, poderżniemy wam wszystkim gardła i zostawimy po kulce dla waszego rządu”. Student czwartego roku Wydziału Geografii na stwierdzenie wykładowcy, że władza radziecka została ustanowiona pod przywództwem wielkiego narodu rosyjskiego, odpark: „Mamy powyżej uszu tego rosyjskiego przywództwa, świetnie damy sobie radę bez niego”. Na wiadomość, że Rada Najwyższa ZSRR planuje przemianowanie Nagrody Stalinowskiej na Leninowska, studentka czwartego roku stwierdziła: „Najpierw nazwą to nagrodą Lenina, a potem nagrodą Iwana”26.

Ściśle tajna „informacja” (sprawkea) KGB z 20 marca 1956 roku oparta na doniesieniach informatorów i dotycząca wypowiedzi oficerów i żołnierzy Zakaukaskiego Okręgu Wojskowego na temat wydarzeń marcowych daje wgląd w sytuację w Gruzji uwzględniający zarówno skargi gruzińskiego personelu, jak i zewnętrzna perspektywę niegruzińskich kadr. 15 marca żołnierz Efrimidze odmówił kategorycznie wykonania rozkazu wykopania transzei; odpowiedział przełożonemu: „Nie jesteś w Moskwie, żeby dawać mi rozkazy”. Następnie nie chciał stanąć w szeregu, a kiedy młodszy sierżant Czarnobyl próbował zmusić go do tego siłą, Efrimidze uderzył go dwa razy i wybił mu dwa zęby. W kwaterze głównej odmówił salutowania oficerom, stwierdzając: „Niech rosyjskim oficerom salutują Rosjanie"27. 16 marca starszy lejtnant Uczeniszwili wyraził oburzenie tym, że wojsko strzelało do demonstrantów, i dodał, że wśród cywilów rozważa się atakowanie napotkanych w pojedynkę żołnierzy ${ }^{28}$.

W niektórych wypowiedziach żołnierze komentowali wprost udział Gruzinów w centralnym kierownictwie. 11 marca $\mathrm{w}$ rozmowie $\mathrm{z}$ informatorem pracownik drukarni Berikaciszwili stwierdził, że to źle, iż we władzach $\mathrm{w}$ Moskwie nie ma ani jednego Gruzina, władze reprezentuja ,,wielkomocarstwowe podejście”, a w związku z tym „nie przypadkiem doszło do tego, że w ostatnich dniach tu w Gruzji ludzie giną i odnoszą rany”29.

Oficerowie niebędący Gruzinami, w większości Rosjanie, którzy - jak stwierdzono - uczestniczyli w dławieniu wystąpień 9 i 10 marca, wyrażali stanowisko dokładnie przeciwne niż ich gruzińscy koledzy. Jak stwierdził ppłk Apkin, ,szczególnie ważne jest uderzenie w inteligencję i studentów, bo większość studentów uczestniczyła w demonstracjach i przemawiała wyrażając nacjonalistyczne poglądy”30. Podpułkownik Rożkow powiedział: „W Gruzji nacjonalizm daje o sobie znać jak w żadnej innej republice, szerzy się korupcja i chaos, ale nikt nie chce z nimi walczyć" 31 .

Pewnym argumentem na rzecz tezy, że postrzegana zmiana statusu republiki przyczyniła się do wybuchu marcowych demonstracji, jest skład społeczny ich uczestników. Jak podkreślają wszystkie relacje, była to głównie młodzież, w tym przypuszczalnie wielu młodych ludzi z marginesu - bez większych szans na zdobycie wykształcenia i zatrudnienia lub takich, którzy co prawda ukończyli studia, ale woleli uniknąć przymusowego stażu (pojechat' po raspriedieleniju) w regionach wiejskich ${ }^{32}$. Jednak spora grupę młodych demonstrantów stanowili awansujący społecznie studenci elitarnych uniwersytetów, w tym wielu członków partii i Komsomołu. Niektórzy byli dziećmi elity

\footnotetext{
${ }^{26}$ Partarchiw CK KPG, f. 14, o. 31, d. 297, k. 49-53.

${ }_{27}$ Partarchiw CK KPG, f. 14, o. 31, d. 297, Informacja o reakcji składu osobowego oddziałów Zakaukaskiego Okręgu Wojennego na wydarzenia związane z rocznica śmierci tow. Stalina, k. 34-35.

${ }^{28}$ Ibidem, k. 35.

${ }^{29}$ Ibidem, k. 36.

${ }^{30}$ Ibidem, s. 28.

31 Ibidem, k. 29.

32 Według raportu KGB część aresztowanych nocą z 9 na 10 marca to osoby „bez określonego zawodu” (SSUSA, f. 6, d. 159, k. 19). Składający samokrytykę na zamkniętych zebraniach partyjnych często podejmowali ten wątek jako jedną z przyczyn rozruchów. Na zamkniętym zebraniu Związku Pisarzy G. Buchnikaszwili podkreślał np., że w ubiegłym roku 16 tys. uczniów ukończyło szkoły, ale tylko połowa postanowiła kontynuować edukację, więc „część z tych, którzy nie mieli nic do roboty, uległa niestety wpływom prowokatorów, biorąc udział w wydarzeniach 5-9 marca bieżącego roku" (Partarchiw CK KPG, f. 14, o. 14, d. 212, k. 37). Jeden z oficerów uczestniczących
} 
władzy - tzw. złotą młodzieżą, wielu reprezentowało też grupę nastawionych na karierę członków średniego szczebla aparatu, nomenklatury i urzędniczej inteligencji33. W raporcie szefa KGB Iwana Sierowa z 22 marca demonstranci określani byli wielokrotnie jako głównie studenci i miejska inteligencja, „wśród których znaczącą część stanowili członkowie partii i Komsomołu"34. Po śmierci Stalina w 1953 roku wśród młodych gruzińskich elit panowało przekonanie, że gruzińscy studenci tracą możliwość ukończenia przodujących moskiewskich uczelni, gruzińscy oficerowie usuwani są ze służby, a szanse na karierę poza granicami republiki gwałtownie maleją ${ }^{35}$.

Szczególnie dużo uwagi śledczy KGB poświęcili przypadkowi Warłama Kuczawy, nauczyciela matematyki i członka partii, który przemawiając 8 marca na manifestacji, uniósł w górę swoją legitymację partyjną, a jego gest powtórzyło wielu zgromadzonych ${ }^{36}$. Do końca 1956 roku w całej republice prowadzono przesłuchania prowadzące do ukarania dziesiątek członków aparatu partyjnego średniego szczebla za udział w marcowych demonstracjach. Wielu z nich otrzymało naganę z wpisem do akt, innych usunięto z partii i zajmowanych stanowisk ${ }^{37}$.

O udział w wydarzeniach 9 marca oskarżono wielu względnie wysoko postawionych członków aparatu. Wiceminister rolnictwa M. Budżaszwili i sekretarz organizacji partyjnej w Ministerstwie Rolnictwa L. Doidżaszwili zostali oskarżeni o sianie propagandy nacjonalistycznej i antyrządowej podczas oficjalnych uroczystości 9 marca, a przewodniczącego egzekutywy dzielnicowego komitetu partii w Garetubani w Tbilisi N. Banetiszwilego oskarżono o „szkalowanie kierownictwa partii i rządu” w dwóch anonimowych listach (z 14 października 1955 r. i 4 marca 1956 r.) $)^{38}$.

Szeroki udział młodych członków partii i działaczy średniego szczebla w gruzińskich wydarzeniach marca 1956 roku prowadzi nieuchronnie do pytania o stopień zaangażowania w nich gruzińskiego kierownictwa partyjnego. Zdaniem Philipa G. Roedera lokalne elity ZSRR, które zyskiwały monopol na mobilizowanie zasobów swoich republik związkowych, mogły je następnie wykorzystywać do umacniania pozycji własnej grupy etnicznej i wysuwania żądań adresowanych do centrali. Monopol mobilizacyjnego instrumentarium to kontrola lokalnych elit nad zasobami „mającymi zasadnicze znaczenie dla długotrwałych działań prowadzonych na szeroka skalę”, 39 , takimi jak dostęp do przestrzeni publicznej, środki umożliwiające zwracanie się do społeczeństwa i prasa w miejscowym języku.

Roeder opisywał wykorzystywanie w latach osiemdziesiątych tych zasobów przez lokalny aparat etniczny republik do wywierania presji na centralę w Moskwie. Wedle dopuszczalnej interpretacji wydarzeń marca 1956 roku w Gruzji kierownictwo republiki lub miejscowe elity celowo organizowały lub podsycały demonstracje, próbując wykorzystywać nacjonalistyczne uczucia, które ujawniły się w odpowiedzi na politykę Moskwy, polegająca na krytyce Stalina i degradacji Gruzji w radzieckiej hierarchii republik.

Niestety w archiwach gruzińskiego Komitetu Centralnego i KGB nie zachowały się dokumenty bezpośrednio potwierdzające jakikolwiek niebudzący wątpliwości udział kierownictwa republiki w podburzaniu mas i organizowaniu demonstracji. Postawa I sekretarza Mżawanadzego i innych przywódców gruzińskiej partii zdradzała nie-

\footnotetext{
w rozpraszaniu demonstracji powiedział informatorowi: „Gruzini demonstrowali nie z powodu problemów materialnych, ale dlatego, że nie mają nic do roboty i łatwo się im żyje”. Inny stwierdził: „Tylko ci, którzy ciężko pracuja, powinni zostać w Gruzji, a resztę trzeba wysłać na nieużytki, żeby tam pracowali, bo tutaj kończą szkoły i próbują zostać w Tbilisi, siedzą bezczynnie, nie mają nic do roboty i tylko się upijaja" (Partarchiw CK KPG, f. 14, o. 31, d. 297, k. 29-30; por. W.A. Kozłow, Massowyje biesporiadki..., s. 157).

33 Według telegramu szefa gruzińskiego KGB Inauriego z 26 marca ponad połowa aresztowanych nocą z 9 na 10 marca (199 na 375) należała do partii lub Komsomołu (SSUSA, f. 6, d. 159, k. 22).

34 SSUSA, f. 6, d. 159, k. 28-30.

35 Wywiad autora z gruzińskim geografem politycznym, przewodniczaccym Gruzińskiej Fundacji Studiów Strategicznych i Międzynarodowych (GFSIS) Aleksandrem Rondelim, Tbilisi, 20 VI 2008.

36 SSUSA, f. 6, d. 405-56, k. 21-22. Inny radziecki oficer uczestniczący w rozpraszaniu tłumu skarżył się informatorowi na złą pracę gruzińskich organizacji partyjnych: „W tym tłumie było dużo komunistów, którzy podczas oczyszczania placu wyjęli z kieszeni legitymacje partyjne. Sami nie zrobili nic, żeby przywrócić porządek, tylko wspierali demonstrantów” (Partarchiw CK KPG, f. 14, o. 31, d. 297, k. 28).

${ }^{37}$ Por. Partarchiw CK KPG, f. 14, o. 31, d. 211, Informacja komitetów KPG o przypadkach zachowań i wypowiedzi antypartyjnych oraz podjętych przeciw nim krokach, k. 5-12, 46-52.

38 Partarchiw CK KPG, f. 14, o. 31, d. 37, k. 2-3.

39 P.G. Roeder, Soviet Federalism and Ethnic Mobilization, „World Politics” 1991, nr 23, s. 200.
} 
pewność i niezdecydowanie. Zdawało się, że nie tyle sterują biegiem wydarzeń, ile na nie reagują. Zagubienie gruzińskiego kierownictwa dobrze ujmuje znacznie późniejszy wywiad ówczesnego szefa KGB w Gruzji Aleksieja Inauriego dla gazety „7 dgde”40: „Podniosłem tę kwestię na posiedzeniu Biura KC Gruzińskiej Partii Komunistycznej: albo powinniśmy pozwolić młodzieży demonstrować publicznie pod pomnikiem Stalina i zapewnić jej bezpieczeństwo, albo publicznie zakazać takiej działalności. Towarzysz odpowiedzialny przed Moskwą zaprotestował: jak mogliśmy pozwolić na coś, co jest sprzeczne z linią XX zjazdu partii? Ale zakaz nie byłby dobry, nie wiedzieliśmy, jaki przyniósłby skutek".

Istnieją dowody pośrednie sugerujące, że zrazu gruzińskie kierownictwo co najmniej biernie sprzyjało demonstracjom. Sam fakt, że zezwolono na nie w pierwszych dniach wydarzeń, a także to, że zgromadzonym dostarczono niezbędnego sprzętu, takiego jak mikrofony, głośniki, wieńce kwiatów i transparenty, wskazuje na cichą zgodę kierownictwa. „Organizowanie żałobnych pochodów nie było wcale trudne, zważywszy przychylne nastawienie władz - pisał Kozłow ${ }^{41}$ - Tradycyjny rytuał i standardowy scenariusz takich oficjalnych wydarzeń opracowane były w najdrobniejszych szczegółach. W każdej szkole i instytucji, w fabrykach i biurach - wszędzie, od Komitetu Centralnego partii po najobskurniejszy miejski urząd - było potrzebne wyposażenie, czyli transparenty, plakaty, portrety przywódców itp. Prawdopodobnie nie wierzono w niejasne pogłoski (dopiero 6 marca najwyżsi przywódcy kraju odczytali »tajne pismo« Komitetu Centralnego KPZR), więc w takich okolicznościach znacznej większości wystarczyła najsłabsza zachęta, aby podjąć działania według znanego wzorca”.

Wynika z tego, że w jakiejś mierze o wybuchu demonstracji zdecydowała naturalna inercja, może też kierownictwo obawiało się, że bezwzględny zakaz demonstrowania przysporzy mu więcej kłopotów. Jednak przynajmniej na początku władze zdawały się prezentować „przyjazne nastawienie”, gotowe pozwolić, by wydarzenia toczyły się swoim biegiem. Jak pisze dalej Kozłow, gruzińskie kierownictwo „patrzyło na rozpalająca się prostalinowską histerię ze słabo skrywaną sympatia. Może nawet chciało wykorzystać masowe demonstracje do wywarcia presji na szefów w Moskwie, by »skorygowali linię partiii"42.

O zaangażowaniu miejscowego kierownictwa partii świadczą też szerzące się pogłoski o treści „tajnego listu” i referatu Chruszczowa o kulcie jednostki. Referat Chruszczowa został przesłany do Gruzji po zakończeniu XX Zjazdu KPZR z zaleceniem utrzymania go w tajemnicy ${ }^{43}$. Referat został odczytany 6 marca na zamkniętym posiedzeniu ścisłego kierownictwa partii obejmującego według korespondenta „Trudu” „około 70-80 osób”44. Oficjalnie informacji tej nie przekazano terenowym organizacjom partyjnym niższego szczebla, udostępniono ją dopiero parę tygodni po wydarzeniach marcowych. Jednak z archiwów KGB i innych raportów wynika jasno, że na długo przed 6 marca uczestnicy demonstracji znali przesłanie „tajnego listu”45. Jak stwierdził w raporcie z 22 marca Sierow, rozpowszechnieniu tej informacji „sprzyjało to, że stały przedstawiciel Gruzji w Moskwie, dowiedziawszy się od delegatów na zjazd, o czym dyskutowano na zamkniętej sesji, zadzwonił do członków kierownictwa Gruzińskiej SRR i powiadomił ich o treści referatu”. Oni zaś, a także sami delegaci, „opowiedzieli swoim znajomym o referacie na temat kultu jednostki”"46.

W depeszach KGB i późniejszych raportach mowa o „organizacyjnym prezydium” (diełowoj prieżidium). O udział w nim byli oskarżani i przyznawali się do niego na przesłuchaniach w organizacjach partyjnych liczni młodzi członkowie partii i studenci. Mimo wysiłków śledczy z KGB, pragnący wykazać bezpośrednie związki tych młodych ludzi z wyższym kierownictwem partii lub istnienie w Gruzji prowadzących skoordynowaną działalność ugrupowań nacjonalistycznych, nie odkryli żadnych niezbitych tego dowodów. Wydaje się jednak, że faktycznie kierownictwo gruzińskiej partii kontaktowało się z ludźmi uchodzącymi za organizatorów i nieoficjalnych przywódców

\footnotetext{
407 dghe, 14 sierpnia 1990.

41 W.A. Kozłow, Massowyje biesporiadki..., s. 157.

42 Ibidem, s. 158.

${ }^{43}$ R. i Ż. Miedwiediew, Nieznany Stalin, Katowice 2006, s. 155-156.

44 „Nie dopustim kritiki Stalina”. Sobytia w Gruzii: mart 1956, „Istocznik” 1995, nr 6.

45 Por. SSUSA, f. 6, d. 159, Telegram Inauriego do Sierowa, 7 III 1956, k. 4.

46 SSUSA, f. 6, d. 159, k. 29.
} 
demonstrantów. 6 marca na polecenie gruzińskiego Biura Politycznego delegacja organizacji partyjnej Tbilisi spotkała się z „organizatorami” na demonstracji pod pomnikiem Stalina i uzgodniła z nimi, że zebrani ludzie nie wyjda poza teren wokół monumentu ${ }^{47}$.

Według protokołów Biura Politycznego Komitetu Centralnego KPG w marcu pierwsze posiedzenie gruzińskiego kierownictwa odbyło się 6 marca, kiedy zwołano specjalną sesję celem przedyskutowania wydarzeń z ostatnich dni w Tbilisi i innych miastach republiki. Na sesji tej postanowiono „wezwać niezwłocznie czołowych działaczy partii i Komsomołu, a także urzędników z MSW i KGB celem przekazania im stosownych instrukcji”48. Na kolejnym posiedzeniu zwołanym 8 marca zaaprobowano omówione poniżej ustępstwa ${ }^{49}$. Tak więc gruzińscy przywódcy śledzili wydarzenia, ale aż do 8 marca nie zdecydowali się na bezpośrednie działania. Do 9 marca nie zajęli oficjalnego stanowiska ani nie ogłosili publicznie żadnych zaleceń. Tego samego dnia, w którym spotkało się Biuro Polityczne KPG, czyli 8 marca, sprawa Gruzji stanęła na posiedzeniu prezydium Komitetu Centralnego w Moskwie, na którym najwyższe kierownictwo KPZR poddało jednoznacznej krytyce bierność gruzińskich towarzyszy50: „Mżawanadze zaspał” - powiedział Mołotow; „Zrobił z siebie głupka” - powiedział Kaganowicz; „To pech. Mżawanadze stracił głowę" - dodał Mołotow.

W późniejszych godzinach Mżawanadze i jego współpracownicy poprosili tych, których uważali za organizatorów demonstracji, o informacje i próbę zapanowania nad sytuacją w kraju. Według raportów z przesłuchań KGB 8 marca sekretarz gruzińskiego KC Michaił Gieorgadze zaprosił dziesięcioosobowa „delegację” protestujących do Komitetu Centralnego na spotkanie z I sekretarzem partii ${ }^{51}$. Mżawanadze przyją ją i poprosił o przedstawienie żądań. Zapowiedział, że „postulaty społeczeństwa będą spełnione” i poprosił delegatów, by poinformowali o tym zgromadzonych. Zanim delegaci opuścili gmach, sekretarz KC Mczedliszwili poprosił ich, by nazajutrz (9 marca) przyszli pod pomnik Stalina przed rozpoczęciem demonstracji, aby „utrzymać porządek” 52.

9 marca o 10.00 Mżawanadze, Gieorgadze i Mczedliszwili „wyszli na podium” pod pomnikiem Stalina i przemówili do zgromadzonych, zapowiadając ustępstwa: w lokalnej prasie ukażą się artykuły o Stalinie, a jeszcze dziś o godzinie 13.00 we wszystkich urzędach i fabrykach odbędą się uroczystości upamiętniające. Przez półtorej godziny tłum spokojnie słuchał przemówień, ale mimo próśb nie rozszedł się po ich zakończeniu. Kierownictwo ponownie zaapelowało do dziesięciu „delegatów”, prosząc o przywrócenie porządku. Ale wtedy jeden z nich, Konstantin Ciciszwili, wezwał zgromadzonych, by zarekwirowali ciężarówki i dołączyli do demonstracji w Gori. Został potem oskarżony o próbę zaognienia sytuacji, lecz podczas przesłuchania bronił się, twierdząc, że chciał w ten sposób pomóc rozproszyć tłum ${ }^{53}$.

Wieczorem 9 marca podjęte przez kierownictwo próby odzyskania kontroli nad sytuacją i pokierowania biegiem wydarzeń drogą ustępstw i współpracy wydawały się więc daremne. W opinii dowódcy oddziałów ochrony pogranicza Zakaukaskiego Okręgu Wojskowego gen. bryg. Bannycha w Tbilisi zapanował chaos i kompletna anarchia. Wszystkie środki transportu - samochody i ciężarówki, autobusy, trolejbusy - znalazły się w rękach tłumu. Auta jeździły po mieście i nieustannie trąbiły. Demonstranci postawili ultimatum - domagali się ustąienia rządu w Tbilisi. Ludzie są niezadowoleni z obecnego kierownictwa ${ }^{54}$.

W notatce przesłanej 9 marca z garnizonu w Tbilisi do KGB czytamy wprawdzie: „Na polecenie rządu Republiki Gruzji wojsko przejmie kontrolę nad strategicznymi obiektami w mieście”, jednak wydaje się, że decyzja o

\footnotetext{
${ }^{47}$ S. Nozadze, 1956 tragikuli 9 marti..., s. 7.

48 Partarchiw CK KPG, f. 14, o. 31, d. 37, k. 4.

${ }^{49}$ Ibidem, k. 5.

50 Archiny Kriemla. Priezydium CK KPSS 1954-1964, t. 1: Czernonyje protokolnyje zapisi zasiedanij. Stienogramy, red. A.A. Fursenko, Moskwa 2004, s. 111-112.

51 Pięciu z nich należało do grupy, która zaapelowała do marszałka Zhu De, dowódcy Chińskiej Armii Ludowo-Wyzwoleńczej i wiceprzewodniczącego Chińskiej Republiki Ludowej, który składał właśnie Tbilisi wizytę oficjalna.

${ }^{2}$ SSUSA, f. 6, d. 375-56, s. 24-25.

53 Ibidem, k. 26-27.

54 Państwowe Archiwum Federacji Rosyjskiej (Gosudarstwiennyj archiw Rossijskoj Fiedieracyi), f. P-9401, o. 1, d. 4442, k. 183.
} 
użyciu wojska zapadła w Moskwie ${ }^{55}$. Kiedy na ulicach pojawiły się radzieckie oddziały, wrogość tłumu wzrosła ludzie zaczęli obrzucać pojazdy wojskowe kamieniami i kijami ${ }^{56}$.

Zamieszanie w najwyższym kierownictwie partii i ambiwalentne reakcje na wydarzenia marcowe mogły być po części skutkiem podziałów w gruzińskim kierownictwie. W Gruzji, jak w pozostałych republikach zwiazkowych ZSRR, kierownictwo opierało się głównie na biegnących z góry na dół sieciach klientelizmu. Ostatnie lata epoki stalinowskiej i bezpośrednio następne nadszarpnęły te sieci w Gruzji. W 1951 r. protegowani ówczesnego I sekretarza Kandida Czarkwianiego i Lawrientija Berii zostali zaatakowani jako odprysk tzw. sprawy mingrelskiej5; na czołowych stanowiskach zastapili ich protegowani Akaki Mgeladzego, który wspierał własnych klientów, podczas gdy I sekretarz partii w Abchazji był prawdopodobnie klientem samego Stalina. Sieć Mgeladzego rozpadła się po śmierci Stalina wiosną 1953 r., kiedy po władzę sięgnął Beria, a jej członkowie nie doczekali się rehabilitacji58. Protegowani Berii, zwłaszcza zajmujący wysokie stanowiska, popadli w niełaskę i zostali odsunięci po jego aresztowaniu w czerwcu 1953 roku. Główny klient Berii w Gruzji, I sekretarz Aleksandre Mircchulawa, został zdjęty ze stanowiska i zastąpiony przez długoletniego klienta Chruszczowa Mżawanadzego 59. Wiosną 1956 Mżawanadze, traktowany z tej racji w Gruzji jako outsider, próbował nadal budować własną sieć klientów i struktury władzy. Ówczesne gruzińskie kierownictwo mogło czuć się więc zalęknione i szczególnie uzależnione od centralnego kierownictwa w Moskwie ${ }^{60}$.

W tej sytuacji wielu członków aparatu partyjno-państwowego średniego i niższego szczebla poczuło, że zagrożona jest ich przyszłość. Biorąc pod uwagę poprzednie polityczne przetasowania, ludzie ci mieli prawo się obawiać, że atak na Stalina oznacza koniec ich kariery i usunięcie ze stanowisk z uwagi na związki z poprzednimi nieformalnymi strukturami władzy. W oczach I sekretarza Mżawanadze i reszty gruzińskiego kierownictwa było to ważne grono potencjalnych zwolenników, z którymi musieli obchodzić się ostrożnie.

Dlatego najdalej idący wniosek, jaki można sformułować na podstawie dostępnych materiałów, jest taki, że gruzińskie kierownictwo zachowało się biernie, nie zahamowało demonstracji, a potem śledziło uważnie bieg wydarzeń, starając się, by mieściły się one w dopuszczalnych granicach. Jedną z przyczyn była próba obniżenia statusu Gruzji przez Moskwę, inną - potrzeba odwołania się do ważnej grupy, jaką byli młodzi działacze średniego i niższego szczebla, a przynajmniej niezrażania ich do siebie. 9 marca kierownictwo zdawało się już nie panować nad wydarzeniami. Słabe i pozbawione autorytetu zmuszone było ustapić przed moskiewską centralą i zgodzić się na wejście do akcji wojsk radzieckich.

Z protokołów gruzińskiego Politbiura wynika, że nadzwyczajne posiedzenie tego grona zwołano na godzinę 3.30 nad ranem 10 marca, kiedy wojsko kończyło operację rozpraszania demonstracji. Na posiedzeniu zdecydowano, że od godziny 7.00 we wszystkich instytucjach i zakładach w Tbilisi odbywać się będą zebrania partyjne mające na celu „potępienie prowokatorów, elementy antyradzieckie i chuliganów” oraz wdrożenie linii partii. Wydano też polecenie, by „w każdym rejonie miasta utrzymywać w gotowości co najmniej 2 tys. komunistów, którzy

\footnotetext{
${ }^{55}$ Kozłow cytuje następująca relację: „Kiedy o 22.25 minister spraw wewnętrznych Dudorow poinformował sekretarza Komitetu Centralnego Aristowa o rosnącym napięciu w mieście, a ten poinformował o tym innego sekretarza Komitetu Centralnego Michaiła Susłowa, okazało się, że ten ostatni »o wszystkim wiedział«, a dowódca Zakaukaskiego Okręgu Wojskowego Fiediukinski »już dostał wszystkie potrzebne instrukcje«. Ostatecznie Moskwa zdecydowała posłać wojsko” (W.A. Kozłow, Massomyje biesporiadki..., s. 171). Także Eduard Szewardnadze mówił w wywiadzie, że Mżawanadze nie mógł sam podjąć takiej decyzji, więc rozkaz musiał przyjść z Moskwy (Wywiad dla autora, Tbilisi, 1 VII 2008). Należy jednak dodać, że według protokołu posiedzenia prezydium w Moskwie 8 marca Susłow powiedział: „Mżawanadze prosi o czołgi” (Archiny Kriemla..., s. 112).

56 SSUSA, f. 6, d. 159, k. 17.

${ }^{57}$ Była to sprawa sfabrykowana w latach 1951-1952 przez Stalina. Mingrelia (po gruzińsku Samegrelo) to region w zachodniej Gruzji, wywodził się stąd Ławrientij Beria. Protegowani przez niego Mingrelowie zostali aresztowani pod zarzutem korupcji i odchylenia burżuazyjnonacjonalistycznego.

58 C. Fairbanks, Clientalism and Higher Politics in Georgia, 1948-53 [w:] Transcaucasia: Nationalism and Social Change, red. R.G. Suny, Ann Arbor 1983. Mgeladze spędził resztę życia jako dyrektor sowchozu w gruzińskim obwodzie Kareli.

${ }^{59} \mathrm{~W}$ przeszłości Mżawanadze był komisarzem politycznym, a potem generałem w armii radzieckiej, współpracował z Chruszczowem na Ukrainie, robiąc karierę polityczną poza Gruzją, głównie w Charkowie, Kijowie i zakarpackich okręgach wojskowych.

${ }^{60}$ Wywiad autora z Eduardem Szewardnadze, Tbilisi, 1 VII 2008.
} 
w razie potrzeby zaprowadzą porządek"61. Ministrowi edukacji Gruzji i rektorom wyższych uczelni polecono relegowanie wszystkich studentów, którzy opuścili zajęcia bez usprawiedliwienia ${ }^{62}$. Interwencja wojsk radzieckich znacznie ograniczyła możliwości gruzińskiego kierownictwa, w pewnym sensie ułatwiając mu wybór, jednak decyzje podjęte 10 marca na posiedzeniu Politbiura dowodza, że gruzińskie władze mogły podjąć zdecydowane kroki w celu stłumienia demonstracji znacznie wcześniej niż wieczorem 9 marca ${ }^{63}$.

Stanowi to przynajmniej pośredni dowód na to, że niepokój spowodowany degradacją Gruzińskiej SRR był nie bez znaczenia dla gruzińskich elit. Poziom motywacji zależał w jakiejś mierze od miejsca w strukturze społecznej. Dla gorzej wykształconych demonstrantów, rekrutujących się z klasy robotniczej i sektora rolnego, a także dla wielu weteranów wojennych dostatecznym powodem do oburzenia był zapewne sam fakt potępienia Wielkiego Przywódcy. Na decyzji innych uczestników demonstracji zaważyło prawdopodobnie to, że po raz pierwszy w życiu mogli powiedzieć publicznie, co myślą. Część upośledzonej społecznie młodzieży miała okazję dać upust frustracji spowodowanej sytuacją życiowa. Jednak nie ulega wątpliwości, że młodzi członkowie partii i inteligenci mieli autentyczne poczucie, iż po śmierci Stalina w roku 1953 status Gruzji obniżył się, a wraz z tym skurczyły się szanse na zdobycie wykształcenia i pracy. Przez wielu przedstawicieli tych grup społecznych polityka destalinizacji prowadzona przez Moskwę musiała być postrzegana jako zapowiedź dalszej degradacji.

Przedstawiona interpretacja rzuca pewne światło na skomplikowany problem, jakim jest miejsce Stalina w tożsamości i mentalności Gruzinów w roku 1956 i dziś. Oferuje bardziej zniuansowaną odpowiedź na pytanie, dlaczego Gruzini poczuli się aż tak pokrzywdzeni destalinizacją i jakoś wyjaśnia paradoks: najgoręcej protestowały te grupy społeczne, zwłaszcza inteligencja, które najbardziej ucierpiały pod rządami Stalina, zarówno osobiście, jak i w sensie doświadczeń krewnych, przyjaciół i znajomych. Interpretacja ta pozwala też zrozumieć głębsze motywy młodych ludzi z kręgów inteligenckich i nomenklaturowych, którym wydarzenia marca 1956 r. pozwoliły po raz pierwszy zasmakować nacjonalistycznej retoryki, a w przyszłych dekadach stać się podporą gruzińskiego radykalnonacjonalistycznego ruchu opozycyjnego ${ }^{64}$.

Jest to też dość mocny argument wspierający interpretację wydarzeń marcowych, wedle której gruzińscy przywódcy swą bierną w najlepszym razie postawą dopuścili do wybuchu protestów, po czym zrozumieli, że 9 marca pod koniec dnia stracili kontrolę nad sytuacja. Nie ma dowodów na to, że owo pasywne przyzwolenie było próbą wywarcia presji na moskiewską centralę, jednak wyjaśnienie to wydaje się co najmniej dopuszczalne, zwłaszcza w połączeniu z innymi czynnikami, takimi jak rozbieżności w łonie gruzińskiego kierownictwa i chęć niezrażania tych, którzy musieli uchodzić w jego oczach za ważny odłam społeczeństwa.

Nie jest szczególnie zaskakujące to, że ostatecznie Moskwa zdecydowała się rozproszyć siłą demonstracje 9 i 10 marca w Tbilisi. Niepokój reżimu wzbudził precedens, jakim były masowy protest w stolicy republiki związkowej, a zwłaszcza jego nacjonalistyczne podłoże. Władze centralne wysłały wojsko, które brutalnie rozproszyło demonstrantów, obarczając zarazem winą tajemniczych „chuliganów i prowokatorów” oraz w mniejszym stopniu lokalne organizacje partyjne, zwłaszcza w szkołach i uniwersytetach, a także Komsomoł, za błędy w „pracy ideowej” i niewłaściwe „wyjaśnianie linii partii” co do zagrożeń związanych z kultem jednostki. Nacjonalistyczny wydźwięk demonstracji był w miarę możności bagatelizowany i klasyfikowany jako nieuzasadniony podziw dla Stalina,

\footnotetext{
${ }^{61}$ Partarchiw CK KPG, f. 14, o. 31, d. 37, s. 5.

${ }^{6}$ Ibidem. Wysłany do Moskwy w maju 1956 r. telegram szefa gruzińskiego KGB Inauriego opisuje szczegółowo działania mające zapobiec ponownym demonstracjom zaplanowanym na 24 III 1956, m.in. utworzenie patroli złożonych z działaczy partii i Komsomołu, wzmocnienie sił policyjnych, utworzenie posterunków kontrolnych dla zahamowania „napływu ludności” do Tbilisi i Gori, wreszcie mobilizację ,aparatu agenturalnego” i wykorzenienie „szerzących plotki” „wrogich elementów” (SSUSA, f. 6, d. 159, k. 23-24).

$63 \mathrm{~W}$ wywiadzie dla autora (Tbilisi, 1 VII 2008) Eduard Szewardnadze powiedział, że jego zdaniem gdyby Mżawanadze od początku wykazał więcej inicjatywy, zwracając się do demonstrantów i uspokajając nastroje, możliwe byłoby bardziej pokojowe rozwiązanie powstałej sytuacji. Miał też wrażenie, że gdyby Mżawanadze mówił lepiej po gruzińsku, łatwiej byłoby mu dotrzeć do społeczeństwa. Dodał, że on sam, jako ówczesny przewodniczący Komsomołu w Kutaisi, przemawiał wtedy do demonstrantów pięć razy, co według niego miało zasadnicze znaczenie dla znalezienia w tym mieście pokojowego rozwiązania.

${ }^{64}$ W.A. Kozłow, Massonyje biesporiadki..., s. 179-182.
} 
zmanipulowany następnie przez „prowokatorów”65. Jak się jednak wydaje, właśnie te nacjonalistyczne wątki protestu poważnie zaniepokoiły centralne kierownictwo w Moskwie, które wkrótce po brutalnej rozprawie (i wbrew ostremu tonowi dekretu z 10 lipca) poszło na ustępstwa wobec Gruzji. Zrezygnowano z czystki w kierownictwie partii i prób obciążenia odpowiedzialnością konkretnych przywódców ${ }^{66}$. Wprost przeciwnie, w następnych latach gruzińskie elity cieszyły się większą niż wcześniej swobodą w zakresie polityki personalnej i większą wolnością w dziedzinie kultury ${ }^{67}$. Większość aresztowanych uczestników protestów wkrótce po cichu zwolniono. Tuż po wydarzeniach marcowych zwyczajem stało się mianowanie rdzennych Rosjan na stanowisko drugiego sekretarza partii, co mogło być odpowiedzią na te wydarzenia. Jednak praktyka ta była częścią polityki ekipy Chruszczowa wobec wszystkich republik związkowych. Zresztą rosyjscy drudzy sekretarze okazywali się bardziej lojalni wobec gruzińskiego kierownictwa niż wobec centrali w Moskwie ${ }^{68}$.

Tak więc bez względu na rolę, jaką de facto odegrało gruzińskie kierownictwo w mobilizowaniu nacjonalistycznych nastrojów i poparcia społecznego podczas wydarzeń marca 1956 roku w reakcji na degradację republiki, wydaje się, że w ostatecznym rozrachunku poprawiły one status Gruzji. Po roku 1956 wypadła ona oczywiście z kategorii „awansujących faworytów”, a reżim dokładał wszelkich starań, by udowodnić, że nie faworyzuje już Gruzinów ${ }^{69}$, jednak Gruzińska SRR nie została zdegradowana do Laitinowskiego statusu „kolonialnego”. Jej położenie bardziej przypominało to, co Laitin określał mianem statusu ,integralnego” i przypisywał republikom bałtyckim. Tamtejsze elity miały ograniczone możliwości w centrum, a zarazem stosunkowo wolną rękę w zakresie polityki personalnej, kulturalnej i wewnętrznej u siebie - dopóki słały do centrali stosowne raporty i ograniczały do minimum przejawy nacjonalizmu, zachowując „instytucjonalne panowanie” na własnym terenie ${ }^{70}$.

Bez względu wreszcie na to, czy podczas wydarzeń roku 1956 gruzińskie kierownictwo faktycznie brało udział w mobilizowaniu protestów, ostateczna nauka, jaką z nich wyciagnęło, była taka, że w relacjach z Moskwą mobilizacja tego typu może okazać się nader skutecznym sposobem osiagania określonych celów. Choć nie jest pewne, czy doszło do tego w roku 1956, w późniejszym okresie gruzińskie elity - i elity polityczne innych republik - coraz jawniej sięgały w relacjach z centralą po ten instrument, osiagając wymierne korzyści, m.in. w kwietniu 1978 r., kiedy doszło do protestów przeciwko zmianie statusu języka gruzińskiego w nowej konstytucji, a także pod koniec lat osiemdziesiątych, w czasach pierestrojki, zarówno w Gruzji, jak i innych republikach ZSRR.

\section{Bibliografia}

Archiny Kriemla. Priezidium CK KPSS 1954-1964, t. 1: Czernonyje protokolnyje zapisi zasiedanij. Stienogramy, red. A.A. Fursienko, Moskwa 2004

J.A. Armstrong, The Ethnic Scene in the Soviet Union: The View of the Dictatorship [w:] The Soviet Nationality Reader: The Disintegration in Context, red. R. Denber, Boulder 1992, s. 227-256 [wyd. 1 [w:] Ethnic Minorities in the Soviet Union, red. E. Goldhagen, New York 1968]

T.K. Blauvelt, Patronage and Betrayal in the Post-Stalin Succession: The Case of Kruglov and Serov, „Communist and PostCommunist Studies" 2008, nr 1 (41), s. 105-120

T.K. Blauvelt, Research Note. The March 1956 Events in Georgia: What do the Archives Hold?, „The Archival Bulletin” (MSW Gruzji), 2 VI 2008

\footnotetext{
${ }^{65} \mathrm{~W}$ tym akapicie sformułowania w cudzysłowie nie pochodza z jednego źródła, lecz powtarzają się wielokrotnie w ówczesnych oficjalnych dokumentach, zob. np. SSUSA, f. 14, o. 31, d. 211; d. 212; d. 37.

${ }^{66}$ To, że nie doszło do czystki, a Mżawanadze i większość jego protegowanych zachowała stanowiska, mogło wynikać po części z tego, że kierownictwo w Moskwie nie miało w Gruzji alternatywnej, godnej zaufania elity. Tym bardziej że Chruszczow i niektórzy jego najważniejsi protegowani (a zwłaszcza szef KGB Sierow) doszli do władzy ledwie trzy lata temu, obalając Berię, mogli więc się obawiać partyjnych kadr republiki, która była jednym z jego bastionów (T.K. Blauvelt, Patronage and Betrayal...). W wywiadzie z 1990 r. dla „7 dghe” szef gruzińskiego KGB Inauri powiedział: „Nie muszę dodawać, że Chruszczow bardzo bał się Gruzinów. Może dlatego mówił na XX zjeździe partii o kulcie Stalina. Dostawał obraźliwe listy, więc czuł się pewniej, mając mnie u boku".

${ }^{67}$ R.G. Suny, The Making of the Georgian Nation, Bloomington 1994, s. 303-304.

68 Wywiad własny z Eduardem Szewardnadze, Tbilisi, 1 VII 2008.

${ }^{69}$ J.A. Armstrong, The Ethnic Scene..., s. 244, podkreśla np., że wprawdzie stopień upartyjnienia w Gruzji był w 1968 r. nadal relatywnie wysoki, jednak po 1956 r. wzrost został ograniczony, prawdopodobnie dlatego, że reżim chciał uniknąć wrażenia, jakoby faworyzował politycznie Gruzinów.

${ }^{70}$ D. Laitin, Identity in Formation..., s. 67.
} 
R. Brubaker, Nationhood and the National Question in the Soviet Union and Post-Soviet Eurasia: An Institutionalist Account, „Theory and Society” 1994, nr 1 (23), s. 47-78

C. Fairbanks, Clientalism and Higher Politics in Georgia, 1948-53 [w:] Transcaucasia: Nationalism and Social Change, red. R.G. Suny, Ann Arbor 1983

I. Inaszwili, „Czemi czkuit komunizms weszenebdi”: interwiu sakartwelos usziszrobis komitetis qopil szeptan - aleksi inaurtan, „7 dghe”, 14 VIII 1990

S. Jones, Georgia: Nationalism from Under the Rubble [w:] Nationalism after Independence: the Post-Soviet States, red. L. Barrington, Ann Arbor 2006

W.A. Kozłow, Massonyje biesporiadki w SSSR pri Chruszrzowie i Brę̧niewrie - 1953-1980 gody, Novosibirsk 1999

D. Laitin, Identity in Formation: The Russian Speaking Populations in the Near Abroad, Ithaca 1998

T. Martin, An Affirmative Action Empire: The Soviet Union as the Highest Form of Imperialism [w:] A State of Nations: Empire and Nation Making in the Age of Lenin and Stalin, red. R.G. Suny, T. Martin, New York 2001, s. 67-90

R. i Ż. Miedwiediew, Nieznany Stalin, Katowice 2006

N. Notadze, Sischliani paraskewi [w:] 9 marti, 1956. Kadrszi da kadrgaret, red. G. Wepchwadze, Tbilisi 2001, s. 94-104

S. Nozadze, 1956 tragikuli 9 marti, Tbilisi 1992

P.G. Roeder, Soviet Federalism and Ethnic Mobilization, „World Politics” 1991, nr 23, s. 196-223

Y. Slezkine, The USSR as a Communal Apartment, or How a Socialist State Promoted Ethnic Particularism [w:] Becoming National: A Reader, red. G. Ely, R.G. Suny, New York 1996, s. 203-238

R.G. Suny, The Making of the Georgian Nation, Bloomington 1994 (wyd. 2) 